University of Nebraska - Lincoln

DigitalCommons@University of Nebraska - Lincoln

$1-2009$

\title{
American Indians and the United States Patent and Trademark Office: The Native American Tribal Insignia Database
}

Charles D. Bernholz

University of Nebraska-Lincoln, cbernholz2@unl.edu

Linda G. Novotny

University of Nebraska - Lincoln, Inovotny1@unl.edu

Ana L. Gomez

University of Nebraska - Lincoln, agomez1@unl.edu

Follow this and additional works at: https://digitalcommons.unl.edu/libraryscience

Part of the Library and Information Science Commons

Bernholz, Charles D.; Novotny, Linda G.; and Gomez, Ana L., "American Indians and the United States Patent and Trademark Office: The Native American Tribal Insignia Database" (2009). Faculty Publications, UNL Libraries. 177.

https://digitalcommons.unl.edu/libraryscience/177

This Article is brought to you for free and open access by the Libraries at University of Nebraska-Lincoln at DigitalCommons@University of Nebraska - Lincoln. It has been accepted for inclusion in Faculty Publications, UNL Libraries by an authorized administrator of DigitalCommons@University of Nebraska - Lincoln. 
Published in Government Information Quarterly 26:1 (January 2009), pp. 180-185; doi 10.1016/j.giq.2008.04.003

From a special issue on "Implementation to Adoption: Challenges to Successful E-Government Diffusion." Copyright @ 2008 Elsevier Inc. Used by permission.

\title{
American Indians and the United States Patent and Trademark Office: The Native American Tribal Insignia Database
}

\author{
Charles D. Bernholz, Linda G. Novotny, and Ana L. Gomez \\ Love Memorial Library, University of Nebraska-Lincoln, Lincoln, NE 68588, USA \\ Corresponding author-C. Bernholz, email cbernholz2@unl.edu ; fax 402 472-5131.
}

\begin{abstract}
The tribal insignia of American Indians offer a distinctive view into the history of these people. Recently, as the result of federal legislation, some of these materials have been brought together, for tribes that are either federally or State recognized entities, as part of the database collection maintained by the United States Patent and Trademark Office (USPTO). This article focuses on the history and use of such images; the policy response by the USPTO to the charge by the Trademark Law Treaty Implementation Act (1998) to examine the USPTO's specific responsibility to protect such official insignia; and the Office's resulting digital product.
\end{abstract}

Keywords: United States Patent and Trademark Office, Native American Tribal Insignia database

Heraldry may be defined as "the systematic hereditary use of an arrangement of charges or devices on a shield" (Woodcock \& Robinson, 1988). Here, the terms "charges" and "devices" depict insignias or figures that convey the desired information. As such, these personal, visual declarations have a long history, beginning in Europe in the mid-twelfth century. Some organizations, such as the Holy See, ${ }^{1}$ have taken a parallel approach. The ever-present, massive pair of St. Peter's keys to the kingdom of Heaven - seen clearly, one in each of his hands, in the painting by Peter Paul Rubens that is now in the Prado Museum in Madrid (Vlieghe, 1972, Fig. 18)-declares on its flag the very foundation of the Church. Following in St. Peter's path, successive Popes have developed personal crests that always augment the image-and the message - of these attributes.

Depictions on shields of individuals offered a slightly different perspective. Military skills, frequently displayed in tournaments, were linked to the participants inside the armor, and these various adorning insignias or images clearly announced who those combatants were. This unique identification might be carried forward, beyond death, by suitably emblazoned catafalques and crypts. In the New World, these colors became nationalistic pronouncements, sometimes as flags upon explorers' ships, or - eventually as those flown in States, such as Maryland's that proclaims even today the two founding families of that domain (Frese, 1991). It does not matter that the latter pennant was officially adopted only in 1904; the legacy is maintained nonetheless.

Nationally, the United States flag has a robust history too, as Guenter's (1990) subtitle -Cultural Shifts from Creation to Codification - affirmed. The thirteen, five-pointed stars that adorned the flag of the Green Mountain Boys (Quaife, Weig, \& Appleman, 1961, Fig. 11), or the six-pointed ones of General George Washington's headquarters standard (Richardson, 1982, Fig. 196), are now well entrenched in United States history, supplemented in number today as a result of the formation of later states. These attributes are no less important than the gold and silver keys on the flag of the Holy See, or the family crests that now herald the State of Maryland. In all three situations, it is an image of a group or a nation, signaling unity and cohesion. ${ }^{2}$ These features, for our national banner, are of such importance that chapter 1 of Title 4 of the United States Code-Flag and Seal, Seat of Government, and the States - speaks for over six pages on its design, dimensions, and usage; the Pledge of Allegiance to it; and appropriate manners and conduct in its deployment (United States Code, 2000, pp. 541-547). ${ }^{3}$

These historical aspects must have been important to all these entities, and the creation of such manifestations in their very public insignia cannot be discarded. Many commercial corporations have been just as enthusiastic about declaring themselves though

1 See the United States Department of State "Background Note" site at http://www.state.gov/r/pa/ei/bgn/3819.htm

2 Cerulo (1995, p. 2) examined national anthems and flags, and how these are created through the influence of "social factors that guide the process of collective symbolization."

3 As an example of these specifications, the diameter of a star must be 0.0616 times the hoist, or width, of the flag (United States Code, 2000, § 1 , p. 543 ). The Department of the Army publishes Army Regulation 840-10: Flags, guidons, streamers, tabards, and automobile and aircraft plates (1998) to cover other display opportunities. 
their trademarks. ${ }^{4}$ Unfortunately, some industrial graphics have discarded their embedded history, as the trademark debacle for the Proctor \& Gamble Company demonstrated (Pederson, 2005). In this instance, the familiar moon and stars trademark-known since the mid-19th century and utilizing thirteen of the latter to echo the rich history of the United States and its own flag-became the central element in the rumor that "P\&G is a corporate agent of Satan" (Procter \& Gamble Co. v. Haugen, 2000). During this controversy, the mark was removed from product packaging. ${ }^{5}$

It is no different with regard to American Indian tribes and their desire to announce and protect their own heritage. The development of the USPTO's Native American Tribal Insignia (NATI) database was intended as a direct government policy statement in support and protection of such tribal assets.

\section{Legislation to create the Native American Tribal Insignia Database}

As part of the federal government's response to the international Trademark Law Treaty of 1994, ${ }^{6}$ the Trademark Law Treaty Implementation Act (1998) contained, in § 302, a miscellaneous provision entitled Official insignia of Native American tribes. In that text, the Commissioner of Patents and Trademarks was empowered, inter alia, to investigate "[t]he means for establishing and maintaining a listing of the official insignia of federally or State recognized Native American Tribes." ${ }^{7}$

In December of 1998, the announcement of the Official insignia of Native American Tribes statutorily required study was made in the Federal Register and outlined the issues to be addressed. This was published, in part, because "[m]embers of Congress [had] received complaints regarding the lack of adequate protection for the official insignia of Native American tribes." 8 A subsequent study was announced the following March (Official insignia of Native American tribes; statutorily required study, 1999).

In an important analysis of the proposed suite, Lury (1999) examined the aspects of $\S 302$ of the Trademark Law Treaty Implementation Act to assess the task thereby presented to the Commissioner to protect tribal insignia. She noted (p. 143) that § 1052 of the Trademark Act of 1946 (60 Stat. 444) identified "certain symbols, words and other matter that are not considered registerable trademark material." Section 1052 of Title 15 of the Unites States Code specifically declares that "[n]o trademark by which the goods of the applicant may be distinguished from the goods of others shall be refused registration on the principal register on account of its nature unless it... (b) Consists of or comprises the flag or coat of arms or other insignia of the United States, or of any State or municipality, or of any foreign nation, or any simulation thereof." The Official insignia of Native American tribes section of the Trademark Law Treaty Implementation Act was designed to amend existing trademark law so that official tribal insignias would be similarly protected. The difficulty arises, however, with the governmental insignia characteristics of these elements in $\S$ 1052(b) of the Trademark Act. Lury concluded that "[b]y analogy section 302 must be limited to those Native American insignia that represent governmental authority, or that when seen cause individuals to associate the insignia with a particular tribe" (p. 146). Simultaneously, in seven pertinent remarks, she emphasized that the communal, non-commercial use of these images by tribes did not adhere to the usage characteristics expressly assigned to trademarks within the law, and so direct application by the tribes for trademark registration of their insignia "is questionable" (p. 152). She concluded that the study, and the eventual creation of an official tribal insignia database within the USPTO, was a sound idea.

Additional public hearings to consider the proposal ${ }^{9}$ were conducted during July 1999, in Albuquerque, San Francisco, and Arlington. A year later, a report collated these hearings, reporting in part that " $[\mathrm{t}]$ hirty-three different groups submitted written comments, some responding to both the December 29, 1998, and March 16, 1999 notices" (Dickinson, 2000). Five of these participants - the American Intellectual Property Law Association, the International Trademark Association, the Mohawk Carpet Corporation, the Pueblo of Zia, and the Tuolumne Band of Me-Wuk Indians - submitted remarks in response to each of the three request opportunities, demonstrating underlying commercial and tribal interests.

The reactions to these discussions and to the requirements of $\S 302$ were reported in the Federal Register as the Establishment of a database containing the official insignia of federally recognized Native American tribes (2001), with proposed procedures to implement the system. As part of this process:

The USPTO will record any official insignia of a Native American tribe submitted in the above manner, if the Commissioner determines that the entity that submitted the request is a Native American tribe recognized by the Federal Government or by one or more state governments.

The Commissioner will determine whether or not the entity that submitted the request is a federally recognized Native American tribe by consulting the list of Native American tribes maintained by the BIA.

If an entity that seeks recordal of its insignia wishes to demonstrate that it is a state-recognized Native American tribe rather than a federally recognized Native American tribe, that entity must provide the Commissioner with either (1) a document issued by a state official that evidences the state's determination that the entity is a Native American tribe, or (2) a citation to a state statute that designates the entity as a Native American tribe (p. 1649; emphasis added).

4 Creating a unique commercial profile includes corporate name development (see this process for a large array of international companies in Room, 2002), as well as eye-catching designs (e.g., Rosentswieg, 1994, and Successful Logos Worldwide: Designers Present Their Best Work, 1992). One highly recognized mark is the winged hourglass of the Longines Watch Company, "the oldest valid trademark in the International Registry at WIPO [World Intellectual Property Organization]," filed in 1893 (Longines Watch Company: Madrid's Oldest Mark, 2005). The company has used this image since 1867, and originally registered it in Switzerland in 1889. Further, the WIPO Magazine declared that "Longines is an instructive case study in the successful exploitation of multiple forms of intellectual property - patents for invention, design, trademarks, and geographical indications." The firm is now a subsidiary of The Swatch Group SA (Pederson, 1999). In the courts, the first alleged adjudication of a trademark infringement is thought to have taken place in Southern v. How (1618). See Stolte (1998) for the history of these proceedings.

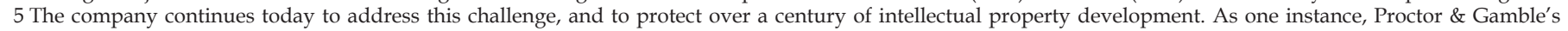
"Trademarks \& Facts" website (http://www.pg.com/company/who_we_are/trademark_corp.jhtml) focuses on their "long-standing commitment to being a good corporate citizen and neighbor in all the places we do business around the world."

6 The complete text of this treaty may be found at http://www.wipo.int/export/sites/www/treaties/en/ip/tlt/pdf/trtdocs_wo027.pdf .

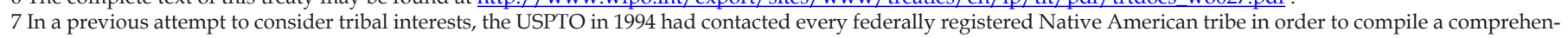
sive list of official insignia, but only about $2 \%$ of the tribes responded (Dickinson, 2000).

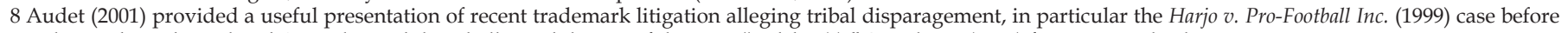
the Trademark Trial and Appeal Board that challenged the use of the term "redskin(s)." See Elman (2006) for more on this litigation.

9 See the public comments, and the transcripts of the remarks, of interested parties on the USPTO Public Hearings web page at http://www.uspto.gov/web/offices/ com/hearings/index.html\#native . In particular, the observations by the Pueblo of Zia of San Ysidro, NM are especially significant, since their Sun Symbol was allegedly taken without tribal permission to become part of the State flag; http://www.uspto.gov/web/offices/com/hearings/natinsig/comments/zia.pdf. 
As such, the recording of tribal insignia in this specific database is not equivalent to registering the image as a trademark, and so any benefits adhering to such registration are not available to the tribes. ${ }^{10}$ Normal trademark registration remains as an alternative option to the tribes for their needs. ${ }^{11}$ The primary use, then, of this collection is to afford interested parties access to official insignia during determinations of registerability of potential trademarks. The USPTO initially estimated 200 annual requests for inclusion, by members of each of the federally and the State recognized tribal groups, at a cost of just ten to twelve minutes of burden time and zero financial outlay per application (Submission of official tribal insignia of federally- and state-recognized Native American tribes for inclusion in a United States Patent and Trademark Office database, 2001). An announcement in the Fall of 2004 disclosed the proposed completed design for the Native American Tribal Insignia Database, at which time the expected number of yearly applicants was reduced to just 15, two-thirds of which were expected to come from federally recognized entities (Native American tribal insignia database, 2004).

\section{American Indian insignias}

Healy and Orenski (2003) have described over 180 tribal flags, many of which incorporate the tribe's seal. These articles were separated into categories based on those tribes that are federally recognized and those that are not. Tribal use of flags is relatively new, beginning with the one presented to the Choctaw Nation in Indian Territory by the Confederate States of America during the Civil War. The Choctaw (and several other eastern tribes) had been removed to Indian Territory in the $1830 \mathrm{~s},{ }^{12}$ and with the onset of the Civil War, had signed treaties with the Confederacy in violation of their negotiations with the United States. The current Great Seal of the Choctaw Nation (see The great seal of the Choctaw Nation, 1956) identifies pictorially the three subdivisions of the nation with a yellow circle, bordered by a blue ring, upon a purple field (Healy \& Orenski, 2003). Today's manifestation is a change from the original light blue flag, with a white-edged red circle in the center that served as the Civil War model between 1861 and $1864 .^{13}$

Further, Carl Waldman, author of the Atlas of the North American Indian (2000), began his Foreword for Healy and Orens- ki's book by stating: "Flags are a loaded concept. For millennia, they have conveyed information about the identity of peoplesinformation that is at once political, historical, cultural, and aesthetic.... Yet, for native peoples, using images to express identity is an ancient tradition." The tribes have celebrated this practice and have shown their intimacy with the environment by adding bison (the Quapaw Tribe of Indians), wolf (the Pawnee Nation of Oklahoma), horses (the Confederated Tribes of the Umatilla Reservation), panther and swan (the Eastern Shawnee Tribe of Oklahoma), killer whale (the Tulalip Tribes), eagle and raven (the Tlingit and Haida Tribes), garfish (the Coushatta Tribe of Louisiana), or entire menageries (the Otoe-Missouria Tribe of Indians) to their standards. The powerful, cultural representation of the turtle-an important earth symbol-appears on many other ensigns (e.g., the Delaware Nation, and the Wyandotte Tribe).

In addition, Lury (1999) mentioned the unlinkable connections between religion and the governing of tribes, many of which pivot upon each group's interactions with nature. She anticipated that protections afforded official tribal insignias, through the NATI process, could concurrently safeguard tribal religious images. In this scenario, the Sun Symbol of the Pueblo of Zia may be considered in the same light as the keys of St. Peter that populate the flag of the Holy See. ${ }^{14}$

\section{Recognized American Indian tribes and treaties}

The issue of official tribal recognition is a significant one that reaches far beyond complying with the USPTO requirements for depositing insignia in their database. In general, there are two systems for recognition: that attained at the federal level, or through State acknowledgment. The creation or the existence of a treaty made with the federal government is a very strong step towards recognition. In all, there are seven federal criteria defined within Title 25, Indians of the Code of Federal Regulations. Section 83.7 identifies these thresholds, but $\S 83.8 \mathrm{c} 1$ states that "[e]vidence that the group has had treaty relations with the United States" (2007) provides unambiguous, previous acknowledgement that expedites current federal recognition. Those tribes or bands that have met these requirements are listed in the current Department of Interior's list of Indian entities recognized and eligible to receive services from the United States Bureau of Indian Affairs (2007). ${ }^{15}$

10 The Serial Numbers in the Table actually declare this non-registration. The United States, as a member of the Paris Convention for the Protection of Industrial Property, adheres to the requirement within the third subsection of Article 6: "The countries of the Union agree to refuse or to invalidate the registration, and to prohibit by appropriate measures the use, without authorization by the competent authorities, either as trademarks or as elements of trademarks, of armorial bearings, flags, and other State emblems, of the countries of the Union, official signs and hallmarks indicating control and warranty adopted by them, and any imitation from a heraldic point of view." Section 1205.02, Article 6ter of the Paris Convention, in Chapter 1200, "Substantive Examination of Applications" of the Trademark Manual of Examining Procedure (see http://tess2.uspto.gov/tmdb/tmep/1200.htm\#_T120502), indicates how such cases are signaled: "When the USPTO receives requests for protection under Article 6ter from the IB [i.e., the International Bureau of the World Intellectual Property Organization], they are assigned serial numbers in the ' 89 ' series code, i.e., serial numbers beginning with the digits '89,' and are sometimes referred to as 'non-registrations.' The USPTO searches its records for conflicting marks, but the requests are not subjected to a full examination by an examining attorney or published for opposition. Information about the designation is entered in the Office's search records, and should be discovered in an examining attorney's search." The full text of the Paris Convention for the Protection of Industrial Property is available at http://www.wipo.int/export/sites/www/treaties/en/ip/paris/pdf/trtdocs_wo020.pdf .

11 For the past twenty years, the Mashantucket Pequot Tribal Nation, in Connecticut, has operated the world's largest casino, the Foxwoods Resort and Casino (see their site at http://www.foxwoods.com/). Their seal/flag consists of a fox standing before a tree on a hill, hence the name of the facility. Their commercial success allowed the tribe in 1994 to donate \$10 million to the Smithsonian Institution to help finance the construction of the National Museum of the American Indian (Healy and Orenski, 2003, p. 129). They have not submitted their flag to this NATI database, but have been granted a number of trademarks incorporating that image.

12 See the five volumes of the Senate's correspondence on the removal of these tribes (United States, 1834).

13 Smith (1975) has a section on the flags of Indian nations, and offers an unofficial, reconstructed color image of the Choctaw flag from the Civil War. He also notes (p. 184) that it is the blue background of this original flag, in concert with the image of an Osage bison-hide shield, that yields today's State flag of Oklahoma (see http://www.fotw.us/flags/us-ok.html ). Section 91 of Title 25 of the Oklahoma Statutes describes the design of the state flag, including its official colors in the Pantone Matching System notation. It is unfortunate that this historically significant banner has not yet been included in the NATI database. We thank Michael White of Queen's University for alerting us to a black and white version of the Great Seal of the Choctaw Nation that is a registered trademark (\# 2837277). In addition, he noted that the Council of the Cowichan Indian Band of British Columbia is a recognized entity under the Indian Act of Canada (see Isaac, 2004 for such federal authority) and that the Band has three United States trademarks, \# 2222979, 2221870, and 2219102. None of these four representations, however, is among the Native American insignia specifically collected within the current NATI system.

14 Recently, Kelley has discussed the Sun Symbol, concluding "[t]he Zia peoples objected to the idea that private businesses might profit from the use of a symbol strongly identified with the community's religious practices. While the situation was eventually addressed by the U.S. Patent and Trademark Office (USPTO) through public hearings, the issue of whether patent and copyright safeguards have adequately protected Indian culture remains insufficiently answered in federal legislative response" (2007).

15 The first list of acknowledged tribes was published in 1979 (Indian tribal entities that have a government-to-government relationship with the United States, 1979). 
Table 1. Serial numbers and word marks in the United States Patent and Trademark Office Native American Tribal Insignia (NATI) database ${ }^{a}$

\begin{tabular}{|c|c|}
\hline \multicolumn{2}{|c|}{ Serial number } \\
\hline 89000518 & $\begin{array}{l}\text { Redding Rancheria Wintu Yana Pit River } \\
\text { http://www.redding-rancheria.com/default.asp }\end{array}$ \\
\hline 89000519 & $\begin{array}{l}\text { Nanticoke Lenni-Lenape Indians of New Jersey, Inc. } \\
\text { http://www.jersey.net/ standingbear/home9.htm }\end{array}$ \\
\hline 89000521 & $\begin{array}{l}\text { Cow Creek Band of Umpqua Tribe of Indians 1853-1982 } \\
\text { http://www.cowcreek.com/ }\end{array}$ \\
\hline 89000633 & $\begin{array}{l}\text { Quinault Indian Nation } \\
\text { http://209.206.175.157/ }\end{array}$ \\
\hline 89000710 & $\begin{array}{l}\text { Seneca-Cayuga Tribe of Oklahoma } \\
\text { http://www.geocities.com/seneca_cayuga/ }\end{array}$ \\
\hline 89000711 & $\begin{array}{l}\text { The Georgia Tribe of Eastern Cherokee P.O. Box } 1993 \text { Dahlonega, } \\
\text { GA } 30533\end{array}$ \\
\hline 89000762 & $\begin{array}{l}\text { Peoria Tribe of Indians of Oklahoma } \\
\text { http://www.peoriatribe.com/ }\end{array}$ \\
\hline 89000951 & $\begin{array}{l}\text { Tuolumne Band of Me-Wuk Indians } \\
\text { http://www.blackoakcasino.com/tribal/tribal.htm }\end{array}$ \\
\hline 89000952 & $\begin{array}{l}\text { Nah-gah-chi-wa-nong Reservation Established by Treaty of } 1854 \\
\text { Fond du Lac } \\
\text { http://www.fdlrez.com/ }\end{array}$ \\
\hline 89000953 & $\begin{array}{l}\text { Upper Sioux Community - Pejuhutazizi Oyate } \\
\text { http:// www.uppersiouxcommunity-nsn.gov/ }\end{array}$ \\
\hline 89000954 & $\begin{array}{l}\text { Nez Perce Tribe Treaty of } 1855 \\
\text { http://www.nezperce.org/content/ }\end{array}$ \\
\hline 89000955 & $\begin{array}{l}\text { Oneida Indian Nation } \\
\text { http://www.oneida-nation.net/ }\end{array}$ \\
\hline 89000956 & Band of Mission Barona 1932 Indians \\
\hline 89000957 & $\begin{array}{l}\text { The Great Seal of the Chickasaw Nation } \\
\text { http://www.chickasaw.net/site06/heritage/250_1044.htm }\end{array}$ \\
\hline 89001000 & $\begin{array}{l}\text { Seminole Tribe of Florida, Inc. In God We Trust } \\
\text { http://semtribeinc.com/ }\end{array}$ \\
\hline 89001051 & $\begin{array}{l}\text { Minnesota Chippewa Tribe Ni-mah-mah-wi-no-min June } 181934 \\
\text { http:// www.mnchippewatribe.org/ }\end{array}$ \\
\hline 89001054 & $\begin{array}{l}\text { Prairie Island Indian Community in the State of Minnesota } \\
\text { http://www.prairieisland.org/index.html }\end{array}$ \\
\hline 89001055 & $\begin{array}{l}\text { Prairie Band Potawatomi Nation } \\
\text { http://www.pbpindiantribe.com/ }\end{array}$ \\
\hline 89001056 & Cachil Dehe Wintun \\
\hline 89001112 & $\begin{array}{l}\text { Official Seal of the California Miwok Tribe } \\
\text { http://www.californiavalleymiwoktribe-nsn.gov/ }\end{array}$ \\
\hline
\end{tabular}

a All seventeen URLs in this list were successfully accessed on April 4, 2008.

Achieving such distinction may be difficult, as the Lumbee Tribe of North Carolina has learned. They were formally recognized by the State in 1885 , and began three years later to acquire federal recognition. The first bill to attain this acknowledgement was introduced in 1899. The later, An act relating to the Lumbee Indians of North Carolina (1956), confirmed their existence as a tribe, but did not convey access to federal programs that other recognized tribes could. Recently, there has been increased activity upon the recognition of this tribe, including hearings statements made on 12 July 2006 in favor of this proposal by Senators Dole and McIntyre. ${ }^{16}$

North Carolina is a particularly interesting example, because the State has such a well-developed recognition program. The
State of North Carolina Administrative Code (2006) has a complete series of rules for which "[o]nly American Indian groups located in North Carolina who can trace their historic origins to indigenous American Indian tribes prior to 1790 are eligible to petition or to be considered for State recognition as an American Indian tribe" (01 NCAC 15. 0203). Other states, primarily in the eastern United States, have similar procedures, and a number of tribes that were originally only recognized at the state level have since gone on to attain federal status. Without one of these two classes of recognition, tribes may not deposit insignia in the NATI database.

\section{Current registrants}

The USPTO provides an FAQ website ${ }^{17}$ for inquiries pertaining to the use of the NATI subsystem. The basic search process employs a specific quoted string plus the Other Data trademark field code designator - "Native American Tribal Insignia" [od] ${ }^{18}$ within the Free Form Search option of the Trademark Electronic Search System (TESS), accessible through the "Trademarks" entry point on the main USPTO internet access point of http://www. uspto.gov/. As defined within the overall system, this FAQ declares that this search method is appropriate "for only - and allthe entities that make up the insignia database" (emphasis added).

The application of this strategy produced, in April 2008, twenty relevant records found in Table 1. Two of the returned entities - for the Tuolumne Band of Me-Wuk Indians and for the Peoria Tribe of Indians of Oklahoma-did not have identified Word Marks. The identification for each of these two applicants was through the Owner Name fields on the records linked to their Serial Numbers, italicized to differentiate them from the others, and placed in the Word Mark column. Chronologically, the Cow Creek Band of Umpqua Tribe of Indians had submitted their insignia in 1991, prior to the implementation of the NATI collation. The rest of the responding tribes have done so since 2001, with the latest application made in June 2007 by the California Miwok Tribe (their image of a fox and an owl adjacent to a map of California). ${ }^{19}$ The collation consists of the twenty Serial Number and Word Mark pairs, sorted by Serial Number. The tribe's URL is provided only if the same insignia is found on both the tribe's page(s), and the supporting TESS page. ${ }^{20}$

\section{Some interesting historical and cultural observations}

- In 1922, the Redding Rancheria was purchased for the three homeless tribes named on the inner ring of their insignia: the Wintu, Yana, and Pit River.

- The Owner Name field of the returned records indicates that all but the Nanticoke Lenni-Lenape Indians are federally recognized tribes. The latter were recognized in 1982 by the State of New Jersey. ${ }^{21}$

- The Cow Creek Band of Umpqua Tribe of Indians 1853-1982 Word Mark identifies their first treaty with the federal govern-

16 See Padget (1997) for more on this journey by the Lumbee.

17 See this aid at http://www.uspto.gov/web/offices/tac/tribalfaq.htm

18 All records, save the ones for the Band of Mission Barona Indians and the Chickasaw Nation, have the phrase "Official Tribal Insignia" in their Description of Mark [de] fields. A full search for this string - "Official Tribal Insignia" [all]-yields three more tribes with Word Marks: an April 2005 filing by the Northern Arapaho Tribe (\# 89001052); a July 2005 one for the Lac Courte Oreilles Governing Board (\# 89001053); and a November 2006 effort of the Georgia Tribe of Eastern Cherokee (\# 89001082). In each of these three cases, "Official Tribal Insignia" appears in the Other Data field. The Eastern Cherokee image returned in this situation is different from the one obtained with the original "Native American Tribal Insignia" [od] search. Further, the Northern Arapaho Other Data field indicates incorrectly that this is the "Official tribal Insignia of the Seminole Tribe of Florida, Inc., mailed to the USPTO on 20050412." Taken together, these findings suggest that there might be other tribal insignia filings that cannot be retrieved by the search strategy specified in the USPTO FAQ for inquiries in the NATI database.

19 The image of this seal is on the tribe's homepage at http://www.californiavalleymiwoktribe-nsn.gov/.

20 The available web sites for the Georgia Tribe of Eastern Cherokee and for the Band of Mission Barona Indians each show a different seal than the one returned by TESS. The Cachil Dehe Band of Wintun Indians does not have a web presence at this time.

21 In their correspondence of November 2001 with the USPTO, accessible through the Trademark Applications and Registrations Retrieval (TARR) system, the Nanticoke Lenni-Lenape Indians of New Jersey declared this State status. In parallel, they are absent from Interior's Indian entities recognized and eligible to receive services from the United States Bureau of Indian Affairs (2007) enumeration. The Georgia Tribe of Eastern Cherokee, however, provided affidavits from the State of Georgia Office of the Governor and the Georgia General Assembly in their June 2003 application that specified that they are a State, and not a federally, recognized body. This information is inconsistent with the indicated federal designation, returned in their TESS data. 
ment, the Treaty with the Umpqua - Cow Creek Band, $1853 .{ }^{22}$ The 1982 date pertains to the band's restoration as a tribe by the federal government, after one hundred thirty years under that treaty (Cow Creek Band of Umpqua Tribe of Indians Recognition Act, 1982).

- The Seneca-Cayuga Tribe of Oklahoma began as part of the Iroquois Confederacy, in New York State, and moved from Ohio to live with the Cherokee in Indian Territory in 1831.

- The Peoria Tribe of Indians of Oklahoma is a confederation of Kaskaskia, Peoria, Piankashaw, and Wea Indians that formed a single tribe in 1854. All lived originally east of the Mississippi River.

- The Tuolumne Band of Me-Wuk Indians is part of the California Miwok Tribe, shown in the list. Their URL and website proudly publicize their Black Oak Casino, named after the acorn that was a staple food item. Their flag shows an oak leaf and acorns.

- One branch of the Minnesota Chippewa, represented here by the Nah-gah-chi-wa-nong Reservation notation in the Word Mark, includes a reference to the Treaty with the Chippewa, 1854 that formed their reservation. ${ }^{23}$ This is one of six Chippewa reservations in Minnesota; it is located near the eastern border of the State.

- The 482 member Upper Sioux live on a 1,140-acre reservation of original Dakota lands, in Minnesota. They operate the Firefly Creek Casino, in Granite Falls, west of Minneapolis.

- The Nez Perce tribe cites their important first treaty, the Treaty with the Nez Perces, 1855..$^{24}$ The insignia contains an image of Chief Joseph, who led the Nez Perce and signed this instrument.

- The Seminole Tribe of Florida uses In God We Trust, the national and the State motto.

- The entire array of Minnesota Chippewa tribes has its own insignia, shown here by the Minnesota Chippewa Tribe Ni-mahmah-wi-no-min June 18, 1934 entry. The date pertains to the Indian Reorganization Act (1934), ${ }^{25}$ which granted the Chippewa the opportunity to create a constitution for their own Nation. This document was formally recognized in 1936 by the Secretary of the Interior.

- The Cachil Dehe Wintun is the Cachil Dehe Band of Wintun Indians of the Colusa Indian Community of the Colusa Rancheria in northern California.

\section{Conclusions}

The creation of the NATI database has several ramifications. First, the enactment of legislation for this program implicitly announced a degree of federal interest in these issues. The postulated investment by interested tribes, of very little time and virtually no money in an application to place an insignia in the NATI, was planned as an effective business strategy for them, since insignia management can be a useful marketing tool for entities that are engaged in, for example, casino gambling. The intellectual property of other, less financially secure tribes might be protected just as effectively.

Second, the management of this system may form an effective shield to protect American Indian tribal image assets targeted for registration by others. This means, in part, that a tribe's sovereignty as a recognized entity is upheld, even if the benefits of ordinary trademark registration are lost. It can simultaneously protect cultural aspects of a tribe's property: it is very clear that, for the tribes noted in this small collection, their flags/seals have been adorned with their own very pertinent historical data, a process that has been lost during the creation, or especially the redesign, of many modern commercial trademarks.

Third, much American history is embedded in these images, as (Smith, 1975) and (Healy and Orenski, 2003) publications relate. This connection between the tribes and the rest of the nation, and the use of such graphics in educational endeavors, will only lead to a better understanding of the peoples among all the citizens of the United States. Further, the dissipation of native stereotyping, as re-exposed during the Harjo litigation processes, might be a dividend of this NATI endeavor, especially if more tribes become involved and help to combat unfair use of their cultural materials.

However, there are shortfalls under this NATI plan. In a demonstration of the concatenation of tribal life, Kremers (2004, p. 3) has written on evolving international interest in the security of "traditional knowledge, genetic resources, and folklore ('TKGRF') of indigenous societies," and on the problems that must be faced with regard to these intellectual properties. She concluded "[d]e facto USPTO leadership of U.S. delegations has had an unnecessary corrosive effect on U.S. credibility in the TKGRF arena, and it should be immediately discontinued. Since TKGRF issues affect the entire spectrum of intellectual property law, the USPTO has in fact no greater subject expertise in TKGRF than counsel from the Copyright Office, the Bureau of Indian Affairs, or other federal agencies formulating TKGRF policy and procedure."

As a supplementary concern, the overall low rate of tribal participation to date has been blamed on the lack of trademark protection for tribal insignias under the NATI program, shelter that is available through normal (although more expensive) trademark registration; on the designed and primary use of the NATI subsystem by USPTO examiners; and/or on the mandatory application process itself. Kremers remarked that "all of the foregoing factors tend to show that the Database, despite official representations to the contrary at international meetings, does not offer any broad or meaningful legal protection for indigenous TKGRF, nor does its creation signify any significant governmental policy interest in indigenous TKGRF protection" (2004, pp. 91-92). If this is the true current perception of the NATI database by the tribes, then greater efforts by the USPTO in the future will be needed to lead to an accumulation of greater focus and confidence by all participants. Kremers' proposals (see especially pp. 92-106) for TKGRF protection-the alleged true purpose of the NATI system proposal-offer such hope, reaching beyond the tribes to involve international cooperation, but still staying linked strongly with a parallel goal to navigate within the bounds of the community's intellectual property laws.

\section{Acknowledgment}

We thank Michael White, Research Services Librarian at the Engineering and Science Library of Queen's University, for his constructive comments made during the development of this article.

22 See Kappler (1904, pp. 606-607) or http://0-digital.library.okstate.edu.library.unl.edu/kappler/Vol2/treaties/ump0606.htm for this text.

23 The document may be considered at Kappler (1904, pp. 648-652), or at http://0-digital.library.okstate.edu.library.unl.edu/kappler/Vol2/treaties/chi0648.htm .

24 This treaty is available at Kappler (1904, pp. 702-706) and at http://0-digital.library.okstate.edu.library.unl.edu/kappler/Vol2/treaties/nez0702.htm .

25 The full title of the legislation was An Act to conserve and develop Indian lands and resources; to extend to Indians the right to form business and other organizations; to establish a credit system for Indians; to grant certain rights of home rule to Indians; to provide for vocational education for Indians; and for other purposes. 


\section{References}

An act relating to the Lumbee Indians of North Carolina. (1956). 70 Stat. 254.

Army Regulation 840-10: Flags, guidons, streamers, tabards, and automobile and aircraft plates, Department of the Army, Washington, DC (1998).

Audet, 2001 M. Audet, Native American tribal names as monikers and logos: Will these registrations withstand cancellation under section 2(a) of the Lanham Act after Harjo v. Pro Football, Inc. (Redskins)?, AIPLA Quarterly Journal 29 (2001), pp. 129-180.

Cerulo, K.A., Identity Designs: The Sights and Sounds of a Nation, Rutgers University Press, New Brunswick, NJ (1995).

Code of Federal Regulations: Title 25 - Indians, Government Printing Office, Washington, DC (2007).

Cow Creek Band of Umpqua Tribe of Indians Recognition Act. (1982). 96 Stat. 1960.

Dickinson, Q.T., Official insignia of Native American tribes: Report pursuant to P.L. 105-330, Government Printing Office, Washington, DC (2000).

Elman, J.T., Can trademark law help minority groups eliminate negative stereotypes? Accessed January 26, 2008 at http:/ / www.law. com/jsp/article.jsp?id=1160557519218 (2006).

Establishment of a database containing the official insignia of federally recognized Native American tribes, Federal Register 66 (6) (2001), pp. 1649-1650.

Frese, D. P., Editor, Maryland Manual, 1991-1992: A Guide to Maryland Government, State Archives, Annapolis, MD (1991).

Guenter, S. M., Editor, The American Flag: Cultural Shifts from Creation to Codification, Farleigh Dickinson University Press, Rutherford, NJ (1990).

Harjo v. Pro-Football Inc., 50 U.S.P.Q.2d (BNA) 1705 (1999).

Healy, D. T., and P. J. Orenski, Native American Flags, University of Oklahoma Press, Norman, OK (2003).

Indian entities recognized and eligible to receive services from the United States Bureau of Indian Affairs, Federal Register 72 (55) (2007), pp. 13647-13652.

Indian Reorganization Act. (1934). 48 Stat. 984.

Indian tribal entities that have a government-to-government relationship with the United States, Federal Register 44 (26) (1979), pp. 7235-7237.

Isaac, T., Aboriginal Law: Commentary, Cases and Materials (3rd ed.), Purich Publishing, Saskatoon, SK (2004).

Kappler, C. J., Indian affairs. Laws and treaties, vol. 2. Treaties. Senate. 58th Congress, 2nd session. Senate Document No. 319, pt. 2 (Serial Set 4624), Government Printing Office, Washington, DC (1904).

Kelley, J. K., Owning the sun: Can native culture be protected through current intellectual property law?, Journal of High Technology Law 7 (2007), pp. 180-202.

Kremers, N., Speaking with a forked tongue in the global dispute on traditional knowledge and genetic resources: Is U.S. intellectual property law and policy really aimed at meaningful protection for Native American cultures?, Fordham Intellectual Property, Media \& Entertainment Law Journal 15 (2004), pp. 1-146.

Longines Watch Company: Madrid's Oldest Mark, WIPO Magazine (no. 2) (2005), pp. 6-7.

Lury, A. A., Official insignia, culture, and Native Americans: An analysis of whether current United States trademark law should be changed to prevent the registration of official tribal insignia, Chicago-Kent Journal of Intellectual Property 1 (1999), pp. 137-157.

Native American tribal insignia database, Federal Register 69 (177) (2004), pp. 55415-55416.

Official insignia of Native American tribes; statutorily required study, Federal Register 63 (249) (1998), pp. 71619-71620.

Official insignia of Native American tribes; statutorily required study, Federal Register 64 (50) (1999), pp. 13004-13005.
Padget, C. D., The lost Indians of the lost colony: A critical legal study of the Lumbee Indians of North Carolina, American Indian Law Review 21 (1997), pp. 391-424.

Pederson, J. P., Editor, International Directory of Company Histories vol. 26, St. James Press, Farmington Hills, MI (1999).

Pederson, J. P., Editor, International Directory of Company Histories vol. 67, Thomson Gale, New York (2005).

Procter \& Gamble Co. v. Haugen, 222 F.3d 1262 (2000).

Quaife, M. M., M. J. Weig, and R. E. Appleman, The History of the United States Flag: From the Revolution to the Present, Including a Guide to its Use and Display, Harper \& Row, New York (1961).

Richardson, E.W., Standards and Colors of the American Revolution, University of Pennsylvania Press, Philadelphia, PA (1982).

Room, A., Encyclopedia of Corporate Names Worldwide, McFarland and Company, Jefferson, NC (2002).

Rosentswieg, G., The New American Logo, Madison Square Press, New York (1994).

Smith, W., The Flag Book of the United States (rev. ed.), William Morrow \& Co, New York (1975).

Southern v. How, 79 Eng. Rep. 1243 (1618).

State of North Carolina Administrative Code, West Group, St. Paul, MN (2006).

Stolte, K.M., How early did Anglo-American trademark law begin? An answer to Schechter's conundrum, Fordham Intellectual Property, Media \& Entertainment Law Journal 15 (1998), pp. 505-547.

Submission of official tribal insignia of federally- and state-recognized Native American tribes for inclusion in a United States Patent and Trademark Office database, Federal Register 66 (73) (2001), pp. 19428-19429.

Successful Logos Worldwide: Designers Present Their Best Work, Nippan Publications, Carson, CA (1992).

The great seal of the Choctaw Nation, Oklahoma Chronicles 33 (1956), pp. 430-433.

Trademark Law Treaty Implementation Act. (1998). 122 Stat. 3064.

United States, Correspondence on the subject of the emigration of Indians, between the 30th November, 1831, and 27th December, 1833, with abstracts of expenditures by disbursing agents, in the removal and subsistence of Indians, Ec. Ec. Furnished in answer to a Resolution of the Senate, of 27th December, 1833, by the Commissary General of Subsistence. Senate. 23rd Congress, 1st session. Senate Document No. 512, pts. 1-5 (Serial Set 244-248), Duff Green, Washington, DC (1834).

United States Code: Title 4-Flag and Seal, Seat of Government, and the States, Government Printing Office, Washington, DC (2000).

Vlieghe, H., Saints, vol. 1. (Corpus Rubenianum Ludwig Burchard, pt. 8), Phaidon, New York (1972).

Waldman, C., Atlas of the North American Indian (rev.ed.), Facts on File, New York (2000).

Woodcock, T., and J. M. Robinson, The Oxford Guide to Heraldry, Oxford University Press, New York (1988).

Charles D. Bernholz is the Government Documents Librarian at the University of Nebraska-Lincoln. He has a BA from Northeastern University; an MA from the University of Guelph; and an MLS from the State University of New York at Buffalo. His research interests focus upon treaties created by the Indian Nations and the governments of North America, and upon the development of federal Indian law in the United States and in Canada.

Linda G. Novotny is the Government Documents Specialist at the University of Nebraska-Lincoln. She has a BS from the University of Nebraska-Lincoln.

Ana L. Gomez is the Government Documents Assistant at the University of Nebraska-Lincoln. Her personal interests range from literature and writing to art. 